\author{
수입 옥수수들의 TME가와 In vitro 방법에 의해 측정한 \\ ME가의 비교 \\ 조중호*. 백인기*. 현 영** \\ 중앙대학교 산업과학대학*, 서울사료 (주)**
}

\title{
Comparison of TME Values of Imported Corns and ME Values Determined by In vitro Method
}

\author{
J. H. Cho*, I. K. Paik* and Y. Hyun** \\ Department of Animal Science and Technology, College of Industrial Science, Chung-Ang University* \\ Seoul Feed Co., Ltd. **
}

\begin{abstract}
An experiment was conducted to compare the ME values of imported corns measured by In vivo (TME) and In vitro (MEn, ME and MEpc) methods and to investigate the true amino acid availability (TAAA) and the true nutrient availability (TNA) of imported corns. For TME assay, twenty four 57-weeks-old Hy-Line roosters were assigned to fasting group (4 roosters) and four corn groups (5 roosters each): USA; corn produced in the United States, ARG; corn produced in Argentina, CHN; regular corn produced in China, CHNP; premium corn produced in China. The MEn, ME and MEpc values were determined by equations based on chemical analysis. The TME value of USA $(3,745 \mathrm{kcal} / \mathrm{kg})$ in as fed basis was significantly $(\mathrm{P}<0.01)$ higher than ARG $(3,555 \mathrm{kcal} / \mathrm{kg})$ and CHNP $(3,518 \mathrm{kcal} / \mathrm{kg})$ but was not significantly different from CHN $(3,671 \mathrm{kcal} / \mathrm{kg})$. The TME value of USA $(4,144 \mathrm{kcal} / \mathrm{kg})$ in DM basis was not significantly different from CHN (4,060 kcal $/ \mathrm{kg})$ and CHNP $(4,008 \mathrm{kcal} / \mathrm{kg})$ but was significantly $(\mathrm{P}<0.05)$ higher than ARG $(4,001$ $\mathrm{kcal} / \mathrm{kg}$ ). There were significant differences in TAAA of phenylalanine, histidine and arginine among imported corns. Those of USA were highest but overall TAAA was not significantly different among imported corns. True availability of NFE of USA, ARG and CHN was significantly $(\mathrm{P}<0.05)$ higher than that of CHNP. However, true availability of crude protein, crude fat, crude fiber and crude ash were not significantly different among corns. The correlation coefficient between TME and MEn value was 0.91 which was significant at $\mathrm{P}<0.1$ but correlation coefficient between TME and ME value and between TME and MEpc value was 0.90 and 0.83 , respectively which was not significant at $\mathrm{P}<0.1$.

In conclusion, US corn was highest in TME values and Chinese premium corn was not significantly different from regular Chinese corn. The MEn value obtained by equation based on chemical analysis may be used as a tool to evaluate TME value of corn.
\end{abstract}

(Key words : Corn, TME, TAAA, MEn, ME, Rooster)

Corresponding author : I. K. Paik, Dept. of Animal Science and Technology, College of Industrial Science, Chung-Ang University, Ansung-Si, Kyunggi-Do, Korea 456-756

E-mail: ikpaik@cau.ac.kr 


\section{I. 서 론}

사료 원료들의 대사 에너지가와 아미노산의 이용율은 사료 원료의 공급원 (품종, 원산지 등) 에 따라 많은 영향을 받는다. 따라서 각 원료 들의 에너지가와 아미노산의 이용율을 고려하 지 않고 총 에너지가나 화학적 분석치 만으로 사료를 제조하게 되면 영양소의 과부족이 생기 고 가축의 생산성이 저하하게 되어 경제적인 손실이 발생하게 된다(남궁 등, 1993). 그러므 로 각 원료들의 대사 에너지가와 아미노산 이 용율을 정확하게 평가하여야 경제적으로 요구 량을 충족시켜줄 수 있다.

사료 원료의 대사 에너지가와 아미노산 이용 율을 측정하기 위해 이용되고 있는 방법들 중 $\mathrm{TME}$ 측정 방법과 TAAA 측정 방법이 닭에서 널리 이용되고 있는데, TME 방법은 Sibbald (1976)에 의해 개발된 방법으로 과거 가금 사료 의 대사 에너지가를 측정하는데 널리 사용되었 던 $\mathrm{AME}$ 측정 방법에서 고려되지 않은 대사 분 에너지와 내생 뇨 에너지를 고려하여 측정 하는 방법으로서 간단하고 빠르며, 경제적인 이점이 있다. 그러나 실험에 필요한 절식구와 시험구의 내생 에너지 및 아미노산 함량이 동 일하지 않을 수 있다는 문제점이 있다 (남궁 등, 1993). 이외에도 실제 생체를 이용하여 대
사 에너지가를 측정하지 않고 사료 내 구성성 분들을 분석하여 계산한 화학적 분석치를 가지 고 대사 에너지가를 계산해내는 공식들이 있다 (Leeson과 Summers, 1976, The Feeding Stuff Regulations, 1991, Carpenter와 Clegg, 1956, Brill Formulation Tutorial, 2007). 하지만 화학적 분석 치로 계산된 대사 에너지가 (In vitro 방법)와 생 체를 이용하여 측정된 대사 에너지가 (In vivo 방법)간의 상관관계가 증명된 문헌은 희소하다.

따라서 본 실험은 수입 옥수수들의 $\mathrm{TME}$ 가 (In vivo 방법)를 측정하고 이를 영양소 성분 분 석을 통해 계산된 (In vitro 방법) 옥수수의 대사 에너지가 $(\mathrm{MEn}, \mathrm{ME}, \mathrm{MEpc}$ )와의 상관계수를 측 정하고 아울러 수입 옥수수의 진정 아미노산 이용율 (TAAA) 및 진정 영양소 이용율 (TNA)을 측정하기 위하여 실시하였다.

\section{ㅁ. 재료 및 방법}

\section{1. 시험 시료}

본 시험에 사용된 시료는 Table 1에서 보는 바와 같이 미국산 (USA), 아르헨티나산 (ARG), 중국산 $(\mathrm{CHN})$, 중국산-premium (CHNP) 등의 4 가지 옥수수를 이용하였다.

Table 1. General composition of test corns by origin

\begin{tabular}{|c|c|c|c|c|}
\hline \multirow{2}{*}{ Items } & \multicolumn{4}{|c|}{ Corns $^{1)}$} \\
\hline & USA & ARG & $\mathrm{CHN}$ & CHNP \\
\hline \multicolumn{5}{|c|}{ 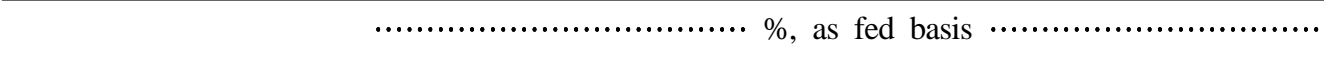 } \\
\hline Moisture & 9.63 & 11.15 & 9.60 & 12.22 \\
\hline Crude protein & 8.81 & 8.76 & 8.46 & 8.52 \\
\hline Crude fat & 3.49 & 4.16 & 3.69 & 3.89 \\
\hline Crude fiber & 1.51 & 1.59 & 1.58 & 1.72 \\
\hline Crude ash & 0.91 & 0.95 & 0.83 & 1.02 \\
\hline NFE & 75.65 & 73.39 & 75.84 & 72.64 \\
\hline
\end{tabular}

1) USA: US No. 3 corn, ARG: Argentine corn, CHN: Chinese corn, regular and CHNP: Chinese corn, premium 


\section{2. 시험 동물 및 시험 설계}

57주령 된 Hy-Line rooster를 시료별로 5수씩 공시하였고 총 4 회에 걸쳐 4 주 간격을 두고 대 사시험을 실시하였다. 수탉의 소화관을 비우기 위해 24시간 절식시킨 다음 시험 시료를 1차, 2차, 3차 시험에서는 $40 \mathrm{~g}$ 씩, 4 차 시험에서는 $30 \mathrm{~g}$ 씩을 강제 급이 시킨 후 36 시간 동안 분뇨 를 채취하였다. 내인성 에너지가와 아미노산을 측정하기 위해 rooster 4수를 절식구로 두어 시 험구와 같은 방법으로 분뇨를 채취하였다. 시 험기간 중 구토한 개체는 시험대상에서 제외하 였다. 채취한 분뇨는 $65^{\circ} \mathrm{C}$ 의 건조기에서 72 시 간 동안 건조한 후 에너지, 아미노산 및 일반 조성분 분석에 이용하였다.

3. 에너지, 아미노산, 일반 성분, 전분 (starch) 및 자당 (sucrose) 분석

시험 시료와 분뇨의 에너지 함량은 시료와 채취한 분 샘플을 $1 \mathrm{~g}$ 씩 펠렛으로 만든 다음 Bomb calorimeter (Parr 1241 Adiabatic Oxygen Bomb Calorimeter, USA)를 사용하여 측정하였 다.

시험 시료와 분뇨의 아미노산 함량은 샘플을 36 시간 동안 $110^{\circ} \mathrm{C}$ 에서 $6 \mathrm{~N} \mathrm{HCl}$ 로 가수분해한 후 시료와 분뇨의 아미노산을 양이온 교환 column으로 분리한 다음 ninhydrin 시약과 반응 시켜 amino acid analyzer(SYKAM Amino Acid Analyzer, Germany)로 분석하였다. 함유황 아미 노산 (cystine, methionine)들은 산가수분해에 파 괴되기 쉬우므로 performic acid (formic acid와 hydrogen peroxide를 9:1의 비율로 혼합한 것)로 가수분해 전에 전처리를 하여 분석하였다.

일반 성분 함량은 AOAC (1990) 방법에 의해 측정하였다.

시험 시료의 전분 함량은 AOAC (1995) 방법 에 따라 샘플을 glucoamylase로 전분을 분해하 여 $540 \mathrm{~nm}$ 의 파장에서 Spectrophotometer (Smart Plus, SP-1900PC, USA)를 이용하여 측정하였다.
시험 시료 내 자당 함량은 샘플을 invertase로 가수분해한 후 가수분해 전후의 glucose를 540 $\mathrm{nm}$ 의 파장에서 Spectrophotometer를 이용하여 측정하였고 가수분해 전후의 glucose 함량차의 값에 계수로 1.9 를 곱하여 산출하였다(주환규 등, 1995).

\section{4. $\mathrm{TME}$ 및 $\mathrm{ME}$ 가 측정 방법}

In vivo 방법을 이용하여 측정된 $\mathrm{TME}$ 가는 Sibbald (1976) 방법에 의하여 계산하였고, In vitro 방법으로 계산된 MEn (Nitrogen corrected ME)은 The Feeding Stuff Regulations (1991), $\mathrm{ME}$ 는 Carpenter와 Clegg (1956) 그리고 MEpc (ME poultry for corn)는 Brill Formulation Tutorial (2007)이 제시한 공식에 따라 각각 산 출하였다.

$$
\mathrm{TME}=\frac{G E_{f} \times X-\left(Y e_{f}-Y e_{c}\right)}{X}
$$

$\mathrm{GE}_{\mathrm{f}}$ : 사료의 총 에너지

$\mathrm{X}$ : 사료 섭취량

$\mathrm{Ye}_{\mathrm{f}}$ : 시험구 닭이 배설한 분뇨 에너지

$\mathrm{Ye}_{\mathrm{c}}$ : 절식구 닭이 배설한 분뇨 에너지

MEn $=0.1551 \times$ crude protein $(\%)+0.3431 \times$ oil (fat, \%) $+0.1669 \times \operatorname{starch}(\%)+0.1301 \times$ sucrose $(\%)$

$\mathrm{ME}=53+38 \times($ crude protein, $\%+2.25 \times$ ether extract, $\%+1.1 \times$ starch, $\%+$ sucrose, $\%$ )

MEpc $=36.21 \times$ crude protein $(\%)+85.44 \times$ fat $(\%)+37.26 \times$ NFE (\%)

\section{5. 진정 아미노산 이용율 (TAAA) 및 진정 영양소 이용율 (TNA)}

진정 아미노산 이용율 (TAAA)은 Sibbald (1976) 그리고 Likuski와 Dorrell (1978)에 의한 $\mathrm{TME}$ 방법을 준용하여 다음 공식으로 계산하 
였다.

$$
\begin{aligned}
& \text { 아미노산섭취량 - (분뇨배설아미 } \\
& \mathrm{TAAA}=\frac{\text { 노산함량 }- \text { 내생아미노산배설량 })}{\text { 아미노산섭취량 }} \times 100
\end{aligned}
$$

일반 성분의 진정 이용율(TNA)은 위의 TAAA 공식을 준용하여 산출하였다.

\section{6. 통계 처리}

시험에서 얻어진 자료의 통계처리는 SAS (1995) GLM (General Linear Model) Procedure를 이용하여 분석하였으며 처리구 평균간의 유의 성은 Duncan's multiple range test를 이용하였다. 그리고 데이터 값이 음의 값이 나온 것들은 0 , 100 이 넘어간 값들은 100 으로 조정하여 통계 처리하였다. TME값과 $\mathrm{MEn}, \mathrm{ME}$ 및 $\mathrm{MEpc}$ 간의 상관관계는 상관계수 $(\mathrm{r})$ 을 구하고 유의성을 검 정하였다.

\section{II. 결과 및 고찰}

수입국에 따른 옥수수들의 진정 대사 에너지 (TME)가를 Table 2에 나타냈다. TME 값은 시 료간에 유의한 $\{$ 풍건물 (as fed) 기준; $\mathrm{P}<0.01$, 건 물 $(\mathrm{DM})$ 기준; $\mathrm{P}<0.05\}$ 차가 있었다. 풍건물 기 준으로 USA의 TME 값이 $3,745 \mathrm{kcal} / \mathrm{kg}$ 으로 가 장 높게 나타났고 그 다음이 $\mathrm{CHN} 3,671$, ARG 3,555 그리고 CHNP $3,518 \mathrm{kcal} / \mathrm{kg}$ 순으로 나타 났다. 건물 기준에서도 USA의 TME 값이 4,144 $\mathrm{kcal} / \mathrm{kg}$ 로 가장 높았으며 $\mathrm{CHN}$ 4,060, CHNP 4,008 그리고 ARG 4,001 kcal/kg 순으로 나타났 다.

수입국에 따른 옥수수의 진정 아미노산 이용 율 (TAAA)을 Table 3에 나타냈다. 아미노산 이 용율은 원산지간에 Phe., His., Arg.를 제외하고 통계적인 유의차 $(\mathrm{P}<0.05)$ 는 없었다. 평균 아미 노산 이용율은 유의한 차이는 없었지만 USA, $\mathrm{ARG}$ 그리고 $\mathrm{CHN}$ 은 각각 $89.4 \%, 89.3 \%$ 그리고 89.1\%로 유사하였으나, CHNP는 86.5\%로 다른
Table 2. True metabolizable energy of corns

\begin{tabular}{|c|c|c|}
\hline \multirow{2}{*}{ Corns $^{1)}$} & \multicolumn{2}{|c|}{$\mathrm{kcal} / \mathrm{kg} \pm \mathrm{SD}$} \\
\hline & As fed basis & DM basis \\
\hline USA & $3,745^{\mathrm{A}} \pm 94.5$ & $4,144^{\mathrm{a}} \pm 104.6$ \\
\hline ARG & $3,555^{\mathrm{B}} \pm 139.7$ & $4,001^{b} \pm 157.2$ \\
\hline $\mathrm{CHN}$ & $3,671^{\mathrm{AB}} \pm 93.6$ & $4,060^{\mathrm{ab}} \pm 103.6$ \\
\hline CHNP & $3,518^{\mathrm{B}} \pm 164.7$ & $4,008^{\mathrm{ab}} \pm 187.6$ \\
\hline SEM & 40.5 & 45.6 \\
\hline
\end{tabular}
determined in roosters

A, B, a, b Means with the different superscripts within a column differ significantly (A, B: $\mathrm{P}<0.01 \mathrm{a}$, b: $\mathrm{P}<0.05$ )

1) USA: US No. 3 corn, ARG: Argentine corn, CHN: Chinese corn, regular and CHNP: Chinese corn, premium

수입 옥수수들의 이용률 보다 낮았다. Phenylalanine 이용율은 USA (100\%)가 CHNP (91.6\%) 보다 유의하게 $(\mathrm{P}<0.05)$ 높았지만 $\mathrm{ARG}(95.8 \%)$ 와 $\mathrm{CHN}(97.6 \%)$ 과는 유의한 차가 없었다. Histidine 또한 USA (94.1\%)가 CHNP (83.16\%) 보다 유의하게 $(\mathrm{P}<0.05)$ 높았지만 $\mathrm{ARG} \mathrm{(86.9 \% )}$ 와 $\mathrm{CHN}(87.8 \%)$ 과는 유의한 차가 없었다. Arginine 이용률은 USA (98.1\%)와 CHN (98.7\%) 이 ARG (89.0\%)와 CHNP (90.4\%) 보다 유의하 게 $(\mathrm{P}<0.05)$ 높았다.

수입 옥수수들의 진정 영양소 이용율은 Table 4에서 보는 바와 같다. 조단백질 이용율 에서 통계적인 유의차는 없었지만 USA(44.1 \%)가 ARG (39.4\%)와 $\mathrm{CHN}$ (38.6\%) 그리고 CHNP (34.4\%) 보다 높은 경향을 보였는데, 이는 TAAA와 같은 경향이었다. 조단백질 이용율이 일반적으로 알려진 단백질 외관상 대사율 60 70\%에 비해 낮게 나타난 것은 사료 강제 급이량이 30 40g으로 정상 섭취량에 비해 적음 으로 인하여 섭취한 단백질을 체단백질 합성에 사용하기 보다는 부족한 에너지를 공급하는데 우선적으로 이용하기 때문인 것으로 보인다. 조지방 이용율에서 유의차는 없었으나 USA 
Table 3. True amino acid availability of corns determined in roosters

\begin{tabular}{|c|c|c|c|c|c|}
\hline \multirow{2}{*}{ Amino acids } & \multicolumn{4}{|c|}{ Corns $^{1)}$} & \multirow{2}{*}{ SEM } \\
\hline & USA & ARG & $\mathrm{CHN}$ & CHNP & \\
\hline \multicolumn{6}{|c|}{ 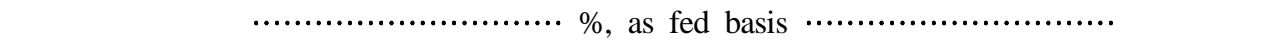 } \\
\hline Asp & 92.8 & 94.7 & 91.8 & 93.5 & 3.11 \\
\hline Thr & 91.1 & 92.9 & 91.2 & 91.5 & 3.18 \\
\hline Ser & 93.2 & 94.7 & 93.8 & 94.2 & 1.91 \\
\hline Glu & 96.8 & 97.3 & 96.0 & 96.8 & 1.28 \\
\hline Pro & 78.8 & 92.1 & 94.7 & 87.6 & 9.61 \\
\hline Gly & 9.3 & 24.1 & 23.6 & 14.6 & 12.94 \\
\hline Cys & 98.5 & 97.5 & 93.6 & 93.6 & 3.38 \\
\hline Val & 93.1 & 95.6 & 86.1 & 92.5 & 3.52 \\
\hline Met & 100.0 & 93.4 & 98.7 & 93.0 & 3.83 \\
\hline Ile & 94.1 & 96.0 & 90.9 & 90.1 & 2.99 \\
\hline Leu & 94.8 & 97.1 & 95.8 & 95.1 & 1.72 \\
\hline Tyr & 98.7 & 99.1 & 96.8 & 91.8 & 3.95 \\
\hline Phe & $100.0^{\mathrm{a}}$ & $95.8^{\mathrm{ab}}$ & $97.6^{\mathrm{ab}}$ & $91.6^{\mathrm{b}}$ & 1.83 \\
\hline His & $94.1^{\mathrm{a}}$ & $86.9^{\mathrm{ab}}$ & $87.8^{\mathrm{ab}}$ & $83.1^{\mathrm{b}}$ & 2.47 \\
\hline Lys & 93.4 & 83.0 & 90.7 & 84.8 & 3.71 \\
\hline Arg & $98.1^{\mathrm{a}}$ & $89.0^{\mathrm{b}}$ & $98.7^{\mathrm{a}}$ & $90.4^{\mathrm{b}}$ & 1.28 \\
\hline Means & 89.4 & 89.3 & 89.1 & 86.5 & 2.90 \\
\hline
\end{tabular}

a, b Means with the different superscripts within a row differ significantly $(\mathrm{P}<0.05)$

1) USA: US No. 3 corn, ARG: Argentine corn, CHN: Chinese corn, regular and CHNP: Chinese corn, premium

(97.7\%)가 ARG (94.9\%), $\mathrm{CHN}(94.9 \%)$ 그리고 게 낮았고 USA, CHN 그리고 ARG 사이에서는 CHNP (94.0\%) 보다 높은 경향을 나타냈다. 조유의한 차는 나타나지 않았는데 이는 TME 결 섬유 이용율에서는 USA (55.8\%)가 다른 구들에 과와 유사하였다.

비해 높았고 $\mathrm{CHN}(42.6 \%)$ ARG (33.8\%) CHNP (33.0\%) 순으로 유의한 차는 나타나지 않았다. 조회분 이용율에서 유의차는 없었지만 CHNP (48.3\%)가 $\mathrm{CHN}(45.2 \%), \mathrm{ARG}(39.5 \%)$ 그리고 생체를 이용하여 측정된 TME가 (In vivo 방 법)와 시료 내 조성분 분석을 통한 화학적 분 석치에 의해 계산된 대사 에너지 (MEn, ME 및 $\mathrm{MEpc}$ )가 (In vitro 방법)의 상관관계를 Table 5 USA (35.9\%) 보다 높게 나타나는 경향을 보였 에 나타냈다. In vivo 방법에 의해 측정된 $\mathrm{TME}$ 다. NFE 이용률에서는 처리간에 유의한 차이가 가와 In vitro 방법에 의해 얻어진 MEn가 사이 $(\mathrm{P}<0.05)$ 있었다. CHNP (93.7\%)가 USA (98.0\%), $\mathrm{CHN}$ (97.9\%) 그리고 ARG (96.3\%) 보다 유의하 의 상관계수는 0.91 로 $\mathrm{P}<0.1$ 이었다. 이는 $\mathrm{MEn}$ 가가 질소를 보정하여 계산된 공식으로 내인성 
Table 4. True nutrients availability of corns determined in roosters

\begin{tabular}{|c|c|c|c|c|c|}
\hline \multirow{2}{*}{ Nutrients } & \multicolumn{4}{|c|}{ Corns $^{1)}$} & \multirow{2}{*}{ SEM } \\
\hline & USA & ARG & $\mathrm{CHN}$ & CHNP & \\
\hline \multicolumn{6}{|c|}{ 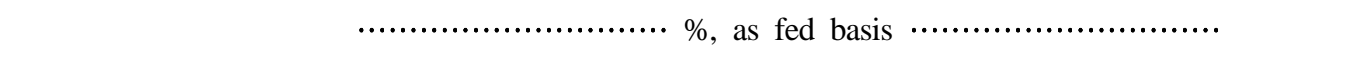 } \\
\hline Crude Protein & 44.12 & 39.41 & 38.57 & 34.42 & 6.31 \\
\hline Crude Fat & 97.70 & 94.87 & 94.87 & 93.97 & 2.03 \\
\hline Crude Fiber & 55.79 & 33.76 & 42.64 & 32.95 & 10.32 \\
\hline Crude Ash & 35.92 & 39.47 & 45.17 & 48.33 & 10.17 \\
\hline NFE & $98.01^{\mathrm{a}}$ & $96.31^{\mathrm{a}}$ & $97.90^{\mathrm{a}}$ & $93.72^{b}$ & 0.68 \\
\hline
\end{tabular}

a, b Means with the different superscripts differ significantly $(\mathrm{P}<0.05)$

1) USA: US No. 3 corn, ARG: Argentine corn, CHN: Chinese corn, regular and CHNP: Chinese corn, premium

Table 5. The contents of starch and sucrose of corns and the comparison of metabolizable energy measured by In vivo and In vitro methods

\begin{tabular}{|c|c|c|c|c|}
\hline Corns $^{1)}$ & USA & ARG & $\mathrm{CHN}$ & CHNP \\
\hline Starch, \% & 67.83 & 64.81 & 67.43 & 63.78 \\
\hline Sucrose, \% & 12.14 & 12.07 & 11.52 & 11.67 \\
\hline $\mathrm{TME}^{2)}$, kcal & 3,745 & 3,555 & 3,671 & 3,518 \\
\hline $\mathrm{MEn}^{3)}$, kcal & 3,696 & 3,626 & 3,664 & 3,542 \\
\hline $\mathrm{ME}^{4)}$, kcal & 3,982 & 3,912 & 3,967 & 3,813 \\
\hline MEpc ${ }^{5)}$ kcal & 3,436 & 3,407 & 3,447 & 3,347 \\
\hline r* (TME vs MEn) & \multicolumn{4}{|c|}{$0.91^{* *}$} \\
\hline r (TME vs ME) & \multicolumn{4}{|c|}{0.90} \\
\hline r (TME vs MEpc) & \multicolumn{4}{|c|}{0.83} \\
\hline
\end{tabular}

1) USA: US No. 3 corn, ARG: Argentine corn, CHN: Chinese corn, regular and CHNP: Chinese corn, premium

2) TME: True metabolizable energy value measured by force feeding

3) MEn: Nitrogen corrected ME value calculated with an equation; MEn (MJ) $=0.1551 \times$ crude protein $(\%)+$ $0.3431 \times$ oil(fat) $(\%)+0.1669 \times \operatorname{starch}(\%)+0.1301 \times \operatorname{sucrose}(\%), 1 \mathrm{~J}=0.239 \mathrm{cal}$

4) ME: ME value calculated with an equation; $\mathrm{ME}(\mathrm{kcal})=53+38 \times$ (crude protein, $\%+2.25 \times$ ether extract, $\%+1.1 \times$ starch, $\%+$ sucrose, $\%)$

5) MEpc: ME poultry for corn calculated with an equation; MEpc (kcal) $=36.21 \times$ crude protein $(\%)+85.44 \times$ fat $(\%)+37.26 \times$ NFE $(\%)$

* r: Correlation coefficient

** Correlation is significant at $\mathrm{P}<0.1$

요인을 고려한 $\mathrm{TME}$ 가와 상관관계가 나타난 것 으로 보인다. 하지만 $\mathrm{TME}$ 가와 $\mathrm{ME}$ 가 그리고 $\mathrm{TME}$ 가와 $\mathrm{MEpc}$ 가 사이에서의 상관계수는 각각 0.90 과 0.83 으로 $\mathrm{P}>0.1$ 이었다. 전체 옥수수의 평 균 $\mathrm{TME}$ 가는 3,622, $\mathrm{MEn}$ 가는 3,632, $\mathrm{ME}$ 가는
3,918, MEpc가는 $3409 \mathrm{kcal} / \mathrm{kg}$ 으로 TME가를 기 준으로 했을 때 $\mathrm{MEn}$ 가는 10 그리고 $\mathrm{ME}$ 가는 $296 \mathrm{kcal} / \mathrm{kg}$ 높게 평가되었지만 $\mathrm{MEpc}$ 가는 213 $\mathrm{kcal} / \mathrm{kg}$ 으로 TME가 보다 낮게 평가되었다. $\mathrm{MEpc}$ 가가 다른 대사 에너지가들 보다 낮게 평 
가된 것은 $\mathrm{MEpc}$ 계산 공식에 $\mathrm{NFE}$ 함량을 고 려한 것으로 NFE 함량 계산에 영향을 미치는 영양소 중 수분 함량 때문인 것으로 생각된다. 따라서 In vitro 방법으로 $\mathrm{TME}$ 가를 추정할 경 우 $\mathrm{MEn}$ 값 산출 공식을 이용하는 것이 적합하 다고 사료된다.

종합적으로 고찰해보면 미국산 옥수수의 $\mathrm{TME}$ 값이 가장 높았고 다음으로 중국산 regular corn이었으며 중국산 premium corn과 아 르헨티나산이 가장 낮았다. 중국산 premium corn의 경우 regular corn에 비해 TME 값 및 성 분상 유의한 차이가 없었다. In vitro 방법으로 $\mathrm{TME}$ 가를 추정할 경우 $\mathrm{MEn}$ 값 산출 공식을 이 용하는 것이 적합하였다.

$$
\text { IV. 요 약 }
$$

수입 옥수수들의 $\mathrm{TME}$ 가를 구하고 진정 아미 노산 이용율 (TAAA) 그리고 여타 진정 영양소 이용율을 측정하기 위하여 57주령 된 Hy-Line rooster 24수를 대사 케이지에 수용하고 미국산 (USA), 아르헨티나산 (ARG), 중국산 (CHN), 중 국산 premium (CHNP) 등 원산지별로 5수씩 공시하였고 내인성 에너지가와 아미노산을 측 정하기 위해 4 수를 절식구로 두어 총 4 회에 걸 쳐 4주 간격을 두고 대사시험을 실시하였다. 얻어진 $\mathrm{TME}$ 값은 In vitro 방법에 의해 측정한 $\mathrm{MEn}, \mathrm{ME}$ 그리고 $\mathrm{MEpc}$ 와의 상관계수를 구하 였다. 풍건물 (as fed) 기준으로 한 $\mathrm{TME}$ 값에 있어서 USA구가 3,745로 ARG구 3,555 그리고 $\mathrm{CHNP}$ 구 3,517 보다 유의하게 $(\mathrm{P}<0.01)$ 높았고 $\mathrm{CHN}$ 구 $3,671 \mathrm{kcal} / \mathrm{kg}$ 와는 유의한 차가 없었다. 건물 $(\mathrm{DM})$ 기준 $\mathrm{TME}$ 값은 $\mathrm{USA}$ 구가 4,144 로 $\mathrm{CHN}$ 구 4,060와 $\mathrm{CHNP}$ 구 4,008과는 유의한 차 가 없었으나 $\mathrm{ARG}$ 구 $4,001 \mathrm{kcal} / \mathrm{kg}$ 보다는 유의 하게 $(\mathrm{P}<0.05)$ 높았다. 옥수수의 phenylalanine, histidine 그리고 arginine의 TAAA는 수입 옥수 수간에 유의한 차이가 있었는데 USA가 가장 높았다. 그러나 전체 아미노산의 TAAA에 있어 서는 유의차가 없었으나 USA 옥수수가 $89.4 \%$
로 다른 원산지 옥수수들인 ARG $89.3 \%, \mathrm{CHN}$ $89.1 \%, \mathrm{CHNP} 86.5 \%$ 보다 다소 높았다. 영양소 이용률에 있어서 NFE 이용율은 USA, ARG 그 리고 $\mathrm{CHN}$ 옥수수가 $\mathrm{CHNP}$ 옥수수 보다 유의 하게 $(\mathrm{P}<0.05)$ 높았으며 조단백, 조지방, 조섬유 및 조회분의 이용율에는 시료간에 유의한 차가 없었다. TME가와 In vitro 방법에 의해 측정된 $\mathrm{MEn}$ 가 사이의 상관계수는 0.91 로 $\mathrm{P}<0.1$ 이었으 나 $\mathrm{TME}$ 가와 $\mathrm{ME}$ 가 그리고 $\mathrm{TME}$ 가와 $\mathrm{MEpc}$ 가 사이에서의 상관계수는 각각 0.90 과 0.83 으로 $\mathrm{P}>0.1$ 이었다.

결론적으로 미국산 옥수수가 $\mathrm{TME}$ 값과 아미 노산 이용율이 가장 높았고 중국산 premium corn은 중국산 regular corn과 비교했을 때 유의 한 차이가 없었다. In vitro 방법으로 옥수수의 $\mathrm{TME}$ 가를 추정할 경우 $\mathrm{MEn}$ 값 산출 공식을 이 용하는 것이 적합하다고 사료된다.

(색인어 ; 옥수수, 진정 대사 에너지, 질소 보정 대사 에너지, 대사 에너지, 가금)

$$
\mathrm{V} \text {. 사 사 }
$$

본 연구는 (주)서울사료의 연구비 지원에 의 해 수행되었음.

\section{VI. 인 용 문 헌}

1. Association of Official Analytical Chemists. 1990. Official Methods of Analysis, Association of Official Analytical Chemists, Washington, D. C.

2. Association of Official Analytical Chemists. 1995. Official Methods of Analysis, Association Official Analytical Chemists, Washington, D. C.

3. Brill Formulation Tutorial. 2007. Brill Co., USA. p. 29.

4. Carpenter, K. J. and Clegg, K. M. 1956. The metabolizable energy of feeding stuffs in relation to their chemical composition. J. Sci. Fd. Agric. 7:45-51.

5. Leeson, S. and Summers, J. D. 1976. Effect of adverse growing conditions on corn maturity and 
feeding value for poultry. Poultry Sci. 55:588-593.

6. Likuski, H. J. A. and Dorrell, H. G. 1978. A bioassay for rapid determinations of amino acid availability values. Poultry Sci. 57:1658-1660.

7. SAS Institute Inc. 1995. SAS User Guide: Statistic Version, 6 Edition, SAS Institute Inc. Cary, NC.

8. Sibbald, I. R. 1976. A bioassay for true metabolizable energy in feedstuffs. Poultry Sci. 55:303-308.
9. The Feeding Stuffs Regulation. 1991. Schedule 9: Method of calculating the energy value of compound feeds. London : HMSO., p. 76.

10. 남궁 환, 백인기, 이희석. 1993. 진정아미노산이 용율 (TAAA) 방법에 의한 단백질 공급원의 아 미노산 이용율 및 대사에너지 측정. 한국가금학 회지. 20(4):189-196.

11. 주환규, 조황연, 박충균, 조규성, 채수규, 마상조. 1995. 식품분석법. 유림문화사. p. 262.

(접수일자 : 2007. 1. 29. / 채택일자 : 2007. 10. 30.) 